HStud 26 (2012)1, 107-122

DOI: 10.1556/HStud.26.2012.1.9

\title{
STRANGE INTERFERENCES: MODERNISM AND CONSERVATISM VS. AVANT-GARDE, HUNGARY, 1910s
}

\author{
GYÖRGY C. KÁLMÁN \\ Institute for Literary Studies, Research Centre for the Humanities, \\ Hungarian Academy of Sciences \\ Budapest, Hungary
}

\begin{abstract}
It is a highly peculiar phenomenon in Hungarian - and perhaps in East and Central European - literature of the early 20th century that Avant-Garde tendencies started to gain some (weak) position parallel with the first wave of Modernism, and when they received - understandably - a rather hostile reaction on the part of Conservative (nationalistic, traditional, anti-Western) literary circles, their reception on the part of the evolving Modernist literature was not much more friendly either. Strangely enough, besides some signals of solidarity and sympathy, the criticisms of Modernism turned against Avant-Garde were in harmony with those formulated by the Conservative circles. However, as the Latin saying goes, "duo cum faciunt idem, non est idem" (that is, when two do the same thing, it is not the same thing) - despite the apparent interference of Modernist and Conservative criticisms aimed against Avant-Garde tendencies, the position of the actors in question was radically different. In what follows, I give a short account of the Avant-Gardists' debate with their Modernist contemporaries and an even shorter account of their debate with their Conservative adversaries.
\end{abstract}

Keywords: avant-garde, modernism, futurism, conservatism, Hungary, Hungarian literature, Lajos Kassák, Mihály Babits

\section{The Nyugat and Kassák}

It is Lajos Kassák, poet and prose writer, whose name still represents the Avant-Garde in Hungarian literature; he is the only one of the pioneers of the movement who made it to get into the present day Hungarian official canon, he has some international recognition for his (typo)graphical work, and perhaps it is only him, at least outside professional circles, who comes to mind whenever Hungarian Avant-Garde is mentioned. He was a great organizer and editor of literary magazines, and he held highly consequent (even stubborn) ideas about the nature and mission of literature and arts. By the time he launched his first bi-weekly literary journal in 1915, A Tett ("The Deed" or "The Activity"), there had been a very influential (and, later, legendary) magazine since 1908, the Nyugat ("West"), the 
first really powerful forum for the Modern literature of the age. The Nyugat's Modernism is a very special blend: it was based largely on the generation principle as well as on this generation's confrontation with nationalistic-Conservative literature (and with right-wing political ideas); it was followed the French Symbolism, the English Post-Victorian and early Modern tendencies and was informed by German Expressionism as well.

Kassák wished to represent another approach: a far more overtly political, Socialist oriented worldview, with strong links to what was regarded as the most progressive tendencies abroad (Futurism, Expressionism etc.), a surprising, even astonishing and raw voice, a new poetics which breaks with possibly all conventions of the past. $A$ Tett was designed to herald this new trend, not primarily against the Nyugat, but claiming independence in every respect.

Thus, the context of the initial steps of the Avant-Garde proper in the Hungarian literature was defined primarily by the Nyugat. Whether this context was sympathetic or offensive is hard to judge: Kassák and the leading figure of the Nyugat, Ernő Osvát, editor, were on pretty good terms, and some of the writers of both groups published in one or another period of their careers in the journal of "the other side" (as Kassák himself did). Moreover, since the Nyugat fostered the idea of generational nature of the new literature, attracting the young artists and writers of the Avant-Garde was one of its aspirations. However, for Kassák's circle it was one of the main ambitions to show its independence and difference which lead to a resistance to Nyugat.

The Nyugat was, so to speak, much more eclectic, more "liberal", more permissive - in the sense that it was its policy to give forum to several different schools, trends, figures and ideas; whereas Kassák's journals (first $A$ Tett and later, as of 1916, MA [“Today"]) represented a more or less homogeneous group.

\section{Futurism: For and Against}

The authors of the Nyugat were well educated, erudite intellectuals who had a wide awareness of what was going on in the sphere of Western literary circles; thus, one of their ambitions was to draw their readers' attention to the most important progressive movements abroad and publish surveys of their contemporaries' works. As early as in 1910, Futurism was thematized in an article by Mihály Babits (an excellent poet and an editor of the Nyugat), with a remarkable ambiguity. In the name of the Nyugat, he refuses any "intellectual kinship" with the Italian Futurism, adding that all that the Futurists were just experimenting with had long been transcended in Hungarian poetry - in the Hungarian context, it appeared only as a sort of parody. However, he hastens to add that "we are also Futurists", and the fog will soon disappear as the sun begins to shine; moreover, he 
repeats in the closure of his survey article that "we are Futurists" - suggesting that the Nyugat will always hail the new tendencies. Whereas Babits was, so to speak, rather cautious in 1910, his reservations later overcame his optimistic expectations: a comment of his in 1918 suggests that in giving account of the scene of poetry one should ignore "the voluntaristic Futurisms" (thus expelling Futurism from the realm of poetry altogether).

The most important poet of the age, who served as a hallmark for the Nyugat as well as for the entirety of modern Hungarian poetry, Endre Ady, formulated a very negative opinion on Futurism (in 1911). The reason why Ady condemns Futurism is just the same as why Béla Balázs praises it - the presence of a conscious and deliberate program which he regards as an ideology surmounting to art. "So I hate Futurists", he claims, and he alludes to the business-like nature of this literary fashion.

The anxiety of Babits was much more serious than that of Frigyes Karinthy (outstanding prose writer, famous of his humorous works and his parodies) and Ernő Bresztovszky (an influential representative of the Socialist oriented but poetically Conservative trend) who both underlined Futurists' attraction to the technological novelties and the modern life (both writings appeared in Nyugat in 1909). Both feel something ridiculous about the language of the Futurists' manifestos as well as their highly ambitious aspirations, they underline, however, that the modern world must be incorporated into the literature of the present day and feel it justified that a group of young artists wishes to make a radical turn in the entrenched course of literary tradition. There is, in both Karinthy's and Bresztovszky's stance, a sort of ambiguity, but - in contrast to Babits's opinion they more definitely vote for Futurism.

Since the Nyugat wished to offer a forum not only for what it regarded as Modernism but as a literary journal designed for a whole generation, being "eclectic" (or, to put it more mildly, more open, more receptive in nature, more liberal in its taste), it had the ambition to encourage the new poetry in general, independent of any trend or movement, no wonder that another leading figure of the magazine, Ignotus (an excellent critic and great organizer of the Nyugat), in 1911, refers to the "revolutionary transformation" of the literature (without any classification or closer definition), of the "Hungarian lyrical poetry, even of the theory of Hungarian versification", and he is happy to salute the emergence of trends themselves as well as their forming movements, with their own prophets, credos and beliefs. He confronts, then, this transformation to what one of the proponents of the Conservative academicians has to say, viz. the protestation against the "excesses" of the new poetry in the name of originality; and it is evident that Ignotus defends the new literature as a whole against this argument of traditionalism (which has ethical overtones as well). 
Among the authors of rather understanding, sympathetic reactions, Béla Balázs (György Lukács's friend, whose Bluebeard's Castle served as a basis for Bartók's opera, later a widely known film theoretician) should also be mentioned (1912). Balázs takes the movement very seriously, and the main argument in his reflections is the strange role of novelty which may blur one's aesthetic judgment. Futurists, he adds (very much similarly to Ady's argument), know very well what they are doing, it is far more than a nonsensical humbug of insane or mentally ill people; what they in fact produce may not be art, but its disquieting nature deserves attention because this way "the sensitivity of our nerves will grow and we will start feeling the corresponding life of forms". Thus, Balázs expects that the new movements will not remain a weird specificity but may shed light to their age and give an impetus for the Modern literature as a whole.

There was but one figure among the authors of the Nyugat who manifested an wholehearted enthusiasm for the movement of the Futurism: it was Dezső Szabó, whose ties with the Nyugat hardly survived World War I, a writer and essayist under the apparent influence of Expressionism, who later became an exponent of the Nationalist (and anti-Semitic) right wing movements. Szabó was a devoted proponent of Futurism and he proposed (in 1912 and 1913) that not only Walt Whitman's "Futurism, creating a new era" but all tiny trends and older schools offering novelty in literature should be subsumed under this label. As the bases of the new art which Szabó regards as Futurism (including all the trends he classifies here), he underlines three tasks: 1 . the past must be broken with, it should be discarded, as well as 2. the cult of the feminine, since "the woman is just a sexual sport for the man of the future", the new art will belong only to the male, and 3. action must be preferred above science and all kinds of reflection. No wonder, then, that it was Szabó who wrote the introductory essay for the first issue of $A$ Tett (remember: it means "The Action", or "The Deed", in harmony with Szabó's 3rd thesis above), Kassák's first Avant-Garde magazine, in 1915 - he hoped that the new generation will realize what he believed were the ideas of Futurism.

\section{An Example of the Conservative Reactions}

To quote yet another criticism aimed against the Avant-Garde, it is high time to turn to the voices outside Nyugat, to an author who may represent the general sentiment of those with an inclination to traditional conventions of poetry, an idea of literature soon to be surpassed and forgotten. Béla Zolnai (who later became an influential and respected professor of stylistics, a major proponent of Geistesgeschichte in Hungary) was one of the very few who took the pains to analyze, whatever shortly, the appearance of the Hungarian Avant-Garde. 
In his study in the same year, 1917, Babits characterizes the judgment of the dominant Conservative canon declared on the literature of the Nyugat as follows: "today, forty years old writers who were trained on serious studies, honestly admiring all the noble traditions and having a completed knowledge of techniques are considered by the official critics as immature revolutionaries..." Thus, the Avant-Garde arrived when the nationalistic-conservative critical scene (including all its participants, from schools to publishing) was preoccupied with the reception, integration or refusal of the classical modern Nyugat. No wonder, then, that Conservative critics turned their attention much more to the poets and authors of the Nyugat (and primarily to Ady, of course) than to the Avant-Garde trends. Zolnai was the only one to publish a thorough and analytical study on the poetry of Kassák's first magazine, only two years after the publication of its first issue.

Zolnai, in his essay, starts with the launching and the program of $A$ Tett and $M A$, and with a sober and discursive manner he relates the problems of war to the ambitions of literary innovation. He regrets that the authors of $A$ Tett are not consequent in their argumentation inasmuch as whereas individualism is preached, they are not individualists in the old sense, since their social commitment cannot be reconciliated with their program aiming at "an active, social literature affecting the great community". If the program of the new magazine were to make aristocratism (exotic and subtle beauties) democratic, similar to the ambitions of Petoffi in the 19th century, if in the center of this new poetry there is activity (and not contemplation or reflection), it is against art for art's sake, it is (as Kassák put it) an "aggressive artistic movement". Thus, Zolnai claims, this program "is similar to that of the Futurists", and it is a "logical reaction to the death poetry of the Decadence", but he doubts both whether this reaction would need a "revolution" and also if the older lyrical poetry of impressions and human feelings would have passed away forever.

After these introductory remarks, Zolnai presents his serious objections. The first point is the demolishment of all aesthetic barriers, the programmatic dissonance, the denial of the artistic, the relativization of the beauty and the ugly. Quoting Babits, he takes the floor against anarchy, and objects the unrestricted widening the scope of possible poetic themes. "One cannot, after all, make an exclusive "salon des refusées"', he notes indignantly. (One should recall that this is exactly what Avant-Garde was up to: to shun the position of being recognized and accepted, to occupy, instead, the place of the marginal, the refused, the outsider.) Zolnai's second point is internationalism, as an offspring of modernity: he even hails the confiscating of the last issue of $A$ Tett, since, for him, pacifism and internationalism is a "life program which is dangerous for the community". His third point concerns the claim for "infinity" - and, along with this, the visionary mode of representation where, instead of a concrete description, the reader is presented a text where "the outlines of the reality are blurred", the images are exaggerated, 
and the words are no more than surrogates - all these lead to a stance which belongs to an extreme form of Expressionism which, for Zolnai, amounts to Futurism (a conceptual confusion somewhat similar to that of the authors of the Nyugat). From this point on, Zolnai starts to pour his evaluations and qualifications - all in all, he condemns everything he hitherto tried to analyze in a reserved way as unintelligible hodgepodge, as a senseless confusion, a comic turbulence; and all this is nothing else but a sheer mannerism, just like free verse, a form degrading verse to prose.

The closing sentences of Zolnai - besides an obligatory gesture of acknowledging the good faith on the part of the Avant-Gardists - contain still another interesting point. The success of the Nyugat, for Zolnai, is not due to the audience's need of a new literature, so Nyugat is not for satisfying the needs of the large reading public but, instead, the Nyugat "has had the material instruments to gather some talented people into its own camp, and it could, from the outset, rely politically on a wide stratum of the reading public." What should that mean? First, it implies the sober insight that a literary magazine needs money for its survival, and this money was acquired by the Nyugat; second, the statement has the less friendly implication that the Nyugat would not, for that matter, interest anybody; third, the acknowledgement that it is the talented people of the generation who joined the camp of the Nyugat; and fourth, it suggests that without the political wind of bourgeois radicalism or liberalism after it, the Nyugat could not possibly sail safely (and that $A$ Tett or the $M A$ have even more suspicious political background, if any).

Zolnai's study is not, however, a typical one; the reserved tone imposed on himself, the scholarly attitude, the argumentation, the consideration of the principles, views of the other party is rather an exceptional case. There are very few texts to illustrate the contemporary reception of the Avant-Garde since most of them are just scornful, incomprehensive or offensive pieces of journalistic writing. The arguments of the conservative camp can, rather, be inferred to, and are not rationally exposed.

\section{Futurism and Avant-Garde}

It seems that by the time of World War I the Nyugat's authors' interest in Futurism slowly faded away or, rather, slightly modified. Before the war, the term "Futurism" was used pretty much as a pars pro toto expression for all sorts of AvantGardisms (and partly, of course, for Futurism proper). But when in 1915 Dezső Kosztolányi (one of the best novelists and poets of the century) reviews Kassák's first volume of his poems, he draws a distinction between this poetry and Futurism ("it has no connection whatsoever with the war poetry living in the European 
common knowledge, old and new, to the poetry of the Futurists"), and connects it, rather, to Expressionism. Since Futurism became rather suspicious, Kosztolányi is forced to find another label, Expressionism, for the poetry he prefers. (This is the first time, by the way, that this term appears in literary context in the Nyugat.)

This gesture of naming (or, rather, re-naming) is highly significant. Giving name to the movement can be the first step towards canonization (or at least domestification). If we know of something what it in fact is (or at least we may attach a name to it, in order to identify it or classify it within a group of other texts), then we may offer it a comfortable place in the row of well known and favorite texts (i.e., the canon), and attach to it a direction of reading, a strategy of interpretation. What Kosztolányi is doing here is not only giving a name but also making a distinction - a differentiation of that name from all the possible others, formulating an opposition between this name and the name of, say, Futurism (or even Impressionism or anything older, more traditional, more established). - It is, however, another issue how Kassák reacts to these gestures of classification, appropriation, and acceptance.

There is, however, yet another reason why Kosztolányi wished to create a distance between Kassák and Futurism.

As it is well known, Italian Futurists did not oppose the war, to say the least: they regarded it as a manifestation of Modernism and technology in their purest form, a climax of a progression, a trial of manly virtues. In the circle of the Nyugat (and in general, among the Hungarian progressive intellectuals), however, the dominant position was pacifism; even if, for instance, Béla Balázs had a short period when he believed that war might be a site for a common suffering where, though descending to the depths of human misery, one should yield the experiences of the essential despair of mankind, the general conviction of his generation was that war is useless, absurd, cruel and dangerous for the society in general. Ady and Babits, notably, were devoted Pacifists. It would be very far-fetched to say that the Nyugat belonged to the political Left of its age, but it is certain that the orientation of the magazine was liberal, as against the ruling conservative, nationalistic and pro-war tendency. It even offered a forum for those attracted by with Socialism.

This ideological constellation, then, may serve as one of the explanations why when the World War I broke out the Nyugat started to be very critical against Futurism. The artistic program of the (Italian) Futurism was very closely interwoven with a political engagement or attraction (to the war). For the time of the war, Babits formulates his opinion in a much more sharp and vigorous way, and he implicitly suggests that the militarism of the Futurists cannot be regarded as independent of the preparations for the war outside the realm of arts, or of the bloodshed which is very much inartistic. Quoting (in 1915) a manifesto of the Futurists (“...Nous, Futuristes, [...] glorifions l'amour du danger et de la violence..."), he 
comments: "the Futurist is happy with the war, he is happy with the suffering, death of his brethren: only because it offers him a spectacle, excitement." Kosztolányi, however, would rather confront Kassák with the Futurism, and ridicules Marinetti - as opposed to Kassák - as somebody who had no idea of the war whatsoever, it is only an object of enthusiasm and exhilarating impressions. For him, Kassák represents much more, just because he is beyond Futurism.

\section{The Babits-Kassák Debate, 1916: Babits}

In 1916, there was a very important debate between Babits and Kassák - a sharp criticism against the new Avant-Garde movement by Babits, and a desperate and bitter reaction on Kassák's part.

Babits's article appeared in the Nyugat in 1916 (No. 17), under the title Ma, holnap, és irodalom ("Today, Tomorrow, and Literature"), dedicated to one of the founding editors of the paper, Aladár Schöpflin. As an introduction, he declares that his aim is to give an account of a generation, and not of one single group, let alone the individual poets themselves. Thus, his approach is quite similar to the generational principle of the Nyugat itself.

The younger generation, says Babits, can be characterized by its fight against traditions. The reason for this behavior, for Babits, is a sociological one - the young was born to a world where the system of literary life is highly hierarchical, where the old rule, and where the young see no future ahead. To turn their attention to the young generation, then, is an obligation the Nyugat must take, since when the Nyugat started it was first received by a similar silence, antipathy and incomprehension. "Nyugat would turn against its own traditions if it did not heed their call." But A Tett (meaning "deed" or "action"), the title of the journal, means for this youth not the creation of something new but rather the destruction of the old, the program of "refusing the traditions".

Not to keep on creating according to the forms already given, neither to build new forms, but to break the old ones, to get rid of and to deny all that is law and form - this is all what the propaganda of $A$ Tett means, it is a real literary anarchy and, let us not delude ourselves, anarchy must be sympathetic for the youth today.

This is not, claims Babits, identical with Futurism, for, as opposed to the latter's militarist character, the generation of $A$ Tett "action" does not mean war activity, and the movement is not individualistic but rather of a collective kind or at least has the aspiration to comprehend the Whole, the cosmos, the diversity, "it wishes to extend itself to the simultaneous sentiments of the whole humanity".

The list of Babits's objection starts with his doubts concerning the program itself - a program for a new movement is, in itself, an obstacle, since "as soon as freedom is transformed into a program, it is not freedom any more but a tie and a 
strait-jacket". A recipe means that "poses" and "strait-jacket" is prescribed to all who subsume themselves to the principles of the movement. It cannot be in harmony with the individualism of Babits that the Avant-Garde, living under the spell of the collectivity and communal nature of creating art, formulates principles, instructions and aims for the individual artists. The next - and more serious objection concerns not the authors' behavior but rather the text formation: i.e., that the younger generation reckons with the traditions, "the program orders, as an obligation, to reject the traditions and forms completely." However, Babits rightly claims, this is foredoomed to failure: traditions, conventions, forms are like language; no (artistic or intelligible) utterance is possible without them. A poetry which aims at giving up all what preceded it is doomed to unintelligibility and inartistic quality.

The next argument is far more doubtful. It goes well beyond theoretical lessons inasmuch as it states that there is no "leap" in art history, there is no revolution, only slow building, the reverence to and cautious modification of older epochs, artists and conventions, and, moreover, every new development has its predecessor - all these, to be sure, are rather observations instead of general truths, and rather ideological ones, or at least relying on a number of presuppositions. One could argue, for instance, against Babits that if this were the case then no surprises or scandals could happen in the history of literature and all sorts of acceptance and reception would be very simple; but what is important here is not the historical arguments and counter-arguments but the vision of undisturbed historical continuity embodied in Babits's line of argumentation. If one sees the history of literature along these lines, under the aegis of respecting the traditions, erudition and perfection in conventions, will have an interest in avoiding obtrusive novelty, and will be averse to the overt breaking the rules.

The new trend has the ambition to look for something new, still, it is embedded in the traditions, it is necessarily tied to the past, it must, however reluctantly, respect the conventions - Babits seeks to discover and justify this status of being preceded in that the new poets themselves refer back to their predecessors; although what they canonize are not their ancestors in Hungarian literary history but rather those in world literature. Babits regards this choice of canonized literature with an apparent resentment, as well as the whole canon created by the AvantGardists, and especially objects the way this canon is formed. He questions the lack or defected nature of informedness, understanding, historical knowledge and poetics, which in turn moves bad, valueless and unknown authors and works right into the center of this canon, and which celebrates a number of texts as modern or brand new developments - but these texts are in fact old, traditional and there is nothing novel in them.

This interpretation of the Avant-Garde, embedding all that strives to be new, surprising, discontinuous into the continuity, belongs, clearly, to a conservative 
interpretive community. It is here with us and informs the critical and lay thinking ever since the beginning of the Avant-Garde, it is present together with the double mill accusation that the Avant-Garde breaks with all traditions - but whenever it happens to adopt a tradition (or can be said to assume it), then it is judged to bring no novelty whatsoever. It is a strange situation for Babits who is the leading figure of a movement to renew the Hungarian literature, viz. the Nyugat; he himself is aware of this delicate position, still, it is difficult to differentiate his arguments from those on the side of conservative literary criticism.

Thus, after Babits declares that "their real kin is Walt Whitman, who has a really cosmic and simultanist vision and sentiment", he withdraws this declaration some lines later: "The authors of $A$ Tett found Walt Whitman as their relative only because of some mere formalities, just as they tend to find a relative in whoever wrote poetry without regular verse forms". Moreover, "poetry in prose as a modern genre is itself an old and accepted form", but - another turn, again - even if it belongs to the tradition, it is not a fruitful part of the repertoire of the poetic creation, since it is monotonous, trivial. To refuse forms amounts to just another restriction which will, again, imprison all free creativity.

Ten years later, Dezső Kosztolányi will have similar arguments in a letter to a very conservative literary critic and literary historian, a revered figure of the old fashioned academy, to make him understand the form of free verse; he writes

\footnotetext{
But to destruct the closed form was, for me and for several of us, was a need of our hearts. We have no cause to make a parade of wanting something "new" with this step. Since this [free verse] is just as old as the bound forms. The Bible is written in free verse, Goethe wrote some free verses as well as Walt Whitman did.
}

Though it may be a question whether it was really Kosztolányi's conviction or just a "political" move on his part to use these arguments, it is clear that he repeats what Babits had to say about modern free verse. Babits expands his argument in his paper to the issues of style and composition, too: to refuse something, he suggests, is always to accept something else, so that just as language (or traditions, or genres) cannot be rejected, put aside or be avoided, the same is true for style and composition. As to style, Babits here makes a serious gesture of concession for the new trends - this time, he admits the legitimacy and forwarding power of the scandalous, offensive and discontinuous changes. "All conventions change", he says, and "the lack of taste" is often the liberation of new areas of phantasy and poetry as is the case of Shakespeare, V. Hugo and Petófi. But on this point all that Babits can say is just an expression of his misgivings concerning the Avant-Gardist taste as a too brave deviation from the old one, thus having a ridiculous touch. He also refers to the erotic element (which he finds unsuccessful), and to the unwillingness to speak in a straightforward, simple way (choosing, instead, a complicated 
and obscure formulation). As a closure, Babits advocates the thesis that "a criticism of a new school of literature is primarily the criticism of its formal instruments" - because, he states, whatever would be new in its content is not too interesting, "to state ideas or to give reports on feelings is not difficult; what is a great thing is to transplant them, to suggest them, and this is possible only with the instruments of the artistic form".

\section{The Babits-Kassák Debate, 1916: Kassák}

Kassák replied to Babits in the next (No. 18) issue of the Nyugat: To Mihály Babits, from under the 'terrible big ash' (“A 'rettenetes nagy hamu' alól Babits Mihályhoz"), which is dedicated (as a challenge to Babits's dedication) "to youngest poets". After a short thank, the reply is a strong refusal of all that Babits stated. First, Kassák denies that the program of $A$ Tett would be a recipe, and by his short summary of the program he wants to refute Babits's arguments concerning the problems of form - the program, he suggests, does not give any instructions relating to forms, only to artistic behavior. Babits, in turn - Kassák declares - does have a very definite program, his recipe is erudition, a careful appropriation and practicing of the past. Whereas the new movement opens the space for the youth, Babits erects a terribly monstrous staircase for them which has to be mounted by experience, erudition and practice.

As to the issue of sophisticated forms, Kassák confronts "primitive" art to the elaborate, technically perfect "artistic" tricks, clearly favoring the former one. Here he opposes Babits's conception of the free verse stating that this is, in fact, the most complicated form due to its inner structure. Moreover, their free verses are the most strictly composed wholes, even in contrast with Whitman.

As far as the predecessors and the cultural (poetic, stylistic, etc.) tradition is concerned, Kassák does not have much more than this to say. He adds, however, that even if Babits has a "thirst for culture", his movement is not up to force a "lunatic illiteracy" to the world, that is, the Avant-Garde is familiar with the knowledge of the traditions, the acquirement of the past.

The voice used in Kassák's reply is not too friendly, and it turns into sharp irony when the author replies to the accusations of "disharmony", "chaoticalness" and "anarchy". It is just the poetry characterized this way what can reflect the experiences of today's youth, and just this is why it may have such a great influence; life is in fact chaotic, there is no harmony in it, the happiness of family hearth is only an illusion - and the poetry must react to this situation accordingly. Hence the need to introduce new topics, to represent subjects hitherto regarded as trivial, ordinary, everyday ones. (It is a strange moment in Kassák's theoretical thinking 
when that topic - the world represented - gets a central position in a quite nonAvant-Gardist way.)

Almost at the end of his reply, that is, in a very emphatic point of the text, Kassák adds a seemingly minor correction. We are, he says,

neither simultanists nor any '-ists' of any sort, and we do not want to form any new literary school; all we want is to be good poets, in a revaluated sense of the word 'good', that is, we want to give good poetry to the newest generation of readers.

Before the interpretation of this part of the text, some words about Babits's reply to Kassák's reaction (Reply - Felelet, Nyugat 1917, No. 18). Babits discusses some of the theses of Kassák in ten short points, apparently sourly, sometimes with an overtly ad hominem argumentation (e.g., that an editor is not entitled to judge the writings published in his magazine, that even if for Kassák free verse is a natural form of expression, it should not be forced to the young poets, etc.).

There is even an explicitly unfriendly ironic point (that $A$ Tett does not succeed in compelling criticism to give account of it at all), but the tenth point (with full of doubts, sourly and parodistically) still formulates some expectant appreciation.

\section{Resistance, Staying Outside, Autonomy}

Going back to the closure of Kassák's reply - when the editor of $A$ Tett, the pioneer and animating personality of the Hungarian Avant-Garde firmly refuses to be classified under any sort of "-ism" label, and even the assumption that he wanted to create a new literary school, he stands up against what Kosztolányi wanted to do, i.e., trying to categorize what he regarded as a new movement. It was the aim of Kosztolányi, among others, to make the Avant-Garde more familiar, more domesticated, as it were, to qualify it as more acceptable and easier to receive for the medium which he himself was familiar with (i.e., for the readers and writers around the Nyugat). This gesture, or, better to say, more than a sheer gesture: an operation of institutionalization, which is to offer legitimacy for the alien popping up in the field, is unacceptable for Kassák, so much so that he even refuses the naming of "new school". This refusal, this courageous, prideful and provocative reaction demonstrates the definitive characteristics of the Avant-Garde in general.

This is a mode of operation, pattern of behavior which characterizes Avant-Garde arts from the beginning until the coming of the Post-Modern. The most dangerous enemy of novelty, scandal or surprise is acceptance, classification, finding place and domestication - this art has a subversive power only until it is not appropriated. And, to be sure, understanding itself is an appropriation, 
either in the sense of empathy or as a cognitive processing. It is the ambition of the Avant-Garde to be simultaneously part of the institutionalized literature (because it badly needs audience, distribution, places for readings and performances, the infrastructure of producing books and magazines), and it also fights against all this, it wants to change the whole scene, to subvert it - and, generally speaking, to get out of the depressing, suppressing, exploiting (or even supporting) influence of money, power and all established institutions of society.

Avant-Garde wishes to stay "unintelligible", something which cannot be classified, which is incomprehensible, something which the frozen institutions cannot handle. There appeared several new forms to circumvent the system of institutions in the last centuries; one of the extremes may be conceptual art (where the "object" or "art object" is not the work itself, it is only a document of the work, since there is no work whatsoever - thus, it is pretty difficult to make goods of it, it is not easy to sell or buy it, and it is a question whether one can make a document of the document, and so on), performance (where the creation of the work of art is not fixed beforehand, neither during its creation, and it cannot be recorded in its entirety posteriorly either; documentation, if any, is necessarily incomplete), or actionism using the body of the artist herself, where it is almost ridiculous to mention work of art, value, material. These forms intentionally draw back the work of art from the world of market (and any other artistic-literary institution), wishing to eliminate the borderline between the artist and anybody else so that even the actors of the field should not be the same as those in the established, traditional field of arts. Multiplication, coquetting with business, reckoning with the individual and unique work of art (from the "objects found" of Beuys to the works of Andy Warhol) amount to this sort of shirking. Postmodernism can perhaps be characterized, among others, by its conciliation with the impossible or ephemeral nature of the scandal, accepts what is given, and its novelty lies in this very ironic subservience.

Kassák' s claim for the status of being unclassified, for the refusal of all qualifications, can be interpreted as a manifestation of the Avant-Gardist behavior which, of course, entails both theoretical and practical literary orientation. One can perhaps give another explanation, not excluding but additional to this one, from another, rather psychological point of view, viz. that this defiant outsider gesture is due to the personality of Kassák, to a deviant, rebellious character, choosing the marginal position for himself in order to remain autonomous. This may be true for the whole Avant-Garde movement: insisting on the right of differing, staying marginal, remaining an outsider not (or not only) as far as the personal life of the artist is concerned but in the activity on the field of literature. Autonomy presented as a value above all other values refers both to the contemporary context (a synchronic aspect) and to the past and the future (a diachronic aspect): acknowledging the relatives, ancestors and followers is always a delicate point. 
One must add, however, that there is a counter-tendency of the refusal of classification (or denial of domestification, understanding and acceptance), viz. the era of the Avant-Garde can also be characterized by a proliferation of programs, movements and schools popularizing themselves. That is, it was the very Avant-Garde which assigned a major importance to manifest and advertise its own (artistic and literary) identity, there is an abounding quantity of self-definitions and self-classifications. And this is also a natural phenomenon: showing the demarcation lines, the main differences, the otherness goes hand in hand with a production and demonstration of the unique, individual, incomparable traits, and the act of giving a name to the movement itself. When Kassák claims that his movement is neither Simultanist nor Futurist, this gesture against classifications does not contradict to the fact that somewhat later he names his movement as Activist - if it is him to give a name to his movement, it is a credible and legitimate step. If somebody else does, it must be a mistake.

All that is said above can be formulated from another aspect, that of the canons. Avant-Garde movements do not - against all their declarations - "eliminate" the canon, it would be possible anyway. They themselves form a continuously changing canon of vague contours which, taken as a list of works, partly overlaps with the ruling canon(s), but taken as a prescription for interpretation, as a set of interpretive conventions is highly different from them. This is exactly what can be tangible in the Whitman case: Babits wishes to set Whitman in the process of literary history, in order to find his proper historical place (that is, as if he knew what place should be found for Whitman), thus, he reads this poetry as part of a process already closed, something uncontinuable, something "readable", without any challenge for new and new interpretations. In the Avant-Gardist canon, however, this poetry becomes the central part of the newly created traditions, because it is strange, because there is something primitively simple, and, thus, can be put into the series defined by ancient art and breaking with the forms. Interpreting Whitman as being in the same series Saint Francis and his Hymn to the Sun must be unacceptable for the Avant-Garde, since that would suggest an interpretation of the free verse as a form being continuously present, independent of history, it would suggest that this form is in close relation to transcendence, it is an ecstatic emanation which strips off, as it were, the form itself. Although some of the Avant-Gardists tend to have an attraction to some form of mysticism, Kassák himself has sometimes an ecstatic voice, Avant-Gardism, however, cannot settle for such an interpretation. Rather, they prefer to regard free verse as an ancient, lost and spontaneous form corresponding to the newly discovered and revived simplicity and directness.

For the Avant-Garde, starting the appropriation is the point where Babits interprets Appollinaire, and what he sees in the French poet is "the simultaneous vision of concurrent colors and events", that is, not too much more than, and not too dif- 
ferent from the poetry of Impressionism, and this appropriation follows when the counter-canon starts to gain the status of an official canon. Preserving and delimitating the canon, a jealous safe-keeping of the proper conventions of interpretation is just as exclusive in nature as the surveillance of any ossified Conservative school.

\section{Conclusions}

To sum up, there is an apparent coincidence of two, otherwise independent, lines of argument against the early Avant-Garde movement in Hungary. One is coming from the Conservative side, a refusal of the anti-traditional, "formless" and "unintelligible" literatures; the other belongs to the Modernist side, itself fighting to be accepted and understood, and having its own war with the (ruling) Conservative medium. These criticisms are centered around the issue of the canon: both for Conservatives and Modernists, changing the canon may be dangerous, and the new forms either not really new, or represent a deviation which goes beyond the limits of intelligibility. The question of individualism vs. collectivism is also raised - both parties feel something controversial in this respect. Political orientation is also a question, although only in the background: while Conservativism is clearly against the anti-war (and even leftist, international) trend of the new movement, Modernists have some suspicion because Futurism (which they more or less identify with the Avant-Garde as a whole) has been notoriously a pro-war, militarist movement, with its celebration of power, fight, war, masculine virtues.

Both in the contemporary context and in the posteriority of the literary history, the canon and the canonized interpretation formed by the Nyugat (i.e., Modernism) turned out to be more powerful; i.e., those of a Modernism which emphasized its ties to the traditions and which had a very cautious relation with the Avant-Garde movements. Throughout the 20th century, the Hungarian AvantGarde had a rather marginal place; both as far as the works and authors themselves, and the strategies of interpretations are concerned. That is, despite of some (again, marginalized) attempts at rewriting literary history shifting the focus on the Avant-Garde movements, the center has always been monopolized by the Nyugat's Modernism. The standard of the age was the classics of this movement, including some outsiders, prominents of the late Realist trends (e.g., the "Popular" or "Völkisch" literature, a school representing the socially engaged, "rural" world view turning against the urban, "l'art pour l'art", aesthetically committed literature) but excluding Avant-Garde tendencies, even understating these trends in great Modernist authors.

Canonically speaking, this approach informed the core of the interpretation of the contemporaries - that is, the canonical status was open only for new works 
which relied on the Modernist (and not the Avant-Garde) traditions, which lend itself to be interpreted along these lines. So for the literary history in the 20th century, there has not been too much place provided for the Avant-Garde in the ruling tradition. The main lesson of the debate treated above, the initial confrontation of the Avant-Garde trends with both Modernism and Conservativism (the strange alliance with the strange interference of arguments) is that still today, the reception (interpretation) of the Avant-Garde poetry (let alone Neo-Avant-Garde) remained basically on the same track which had been laid long before. The debate itself, of course, is only a good and exceptionally clear illustration, not the cause itself; it shows the origins of a long lasting set of arguments, a tradition which has its roots in both Conservative and (a special) Modernist approach.

The Nyugat created for itself a tradition which was wide enough to confine, for instance, the revolutionary work of Bartók (or Ady); and one can argue for an alternative literary history stating that in the tradition (and canon) formed by Modernism there must be a place for the Avant-Garde as a subversive, yet impulsive force. Or, from another point of view which regards Postmodernism as the telos of the whole literary historical process, the central category could be the position of the subject, in which case the revision of this history should start from Romanticism, and revaluate Modernism from this aspect - it would then blur the (traditional) differences between Modernism and Avant-Garde, thus emancipating the latter. This approach would also be opposed to the ideological character of the earlier (Modernism based) conventions of interpretation which emphasize continuity, "progressive" traditions etc.

The debate, then, is something which remained, even today, strikingly vivid. Unfortunately enough. Suffice it to look at the school textbooks or the repertoire of the concert halls to see how Classical Modernism dominates present Hungarian culture, and how difficult it is to make it understood that Avant-Gardism (and whatever came after it) is not something unintelligible, obscure and negligible but a forceful trend which has formed (and did not cease to form) what we now regard as the literature of the 20th century. 